\title{
The influence of isolation stress on the (re)organization of cell walls in protoplasts of in vitro recalcitrant plants
}

\author{
Alina Wiszniewska*, Barbara Piwowarczyk, Anna Pindel \\ Department of Botany and Plant Physiology, Faculty of Horticulture, University of Agriculture in Krakow, Kraków, Poland \\ *Corresponding author: a.wiszniewska@ogr.ur.krakow.pl
}

\begin{abstract}
A study of cell-wall regeneration was conducted on protoplast cultures of four recalcitrant plant species: yellow lupin and grasspea (grain legumes), and also hyacinth and asparagus (ornamental monocots). The rate of cell wall resynthesis was investigated together with the arrangement of cellulosic fibers on the surface of protoplast-derived cells. Localization of arabinogalactan proteins in cell walls was also performed. Quick cell wall renewal occurred in grasspea and hyacinth cultures, where the percentage of protoplast-derived cells after $24 \mathrm{~h}$ of culture accounted for $45-50 \%$. In contrast, the presence of cell walls in half of the population was not observed in asparagus and lupin cultures until 5 and 7 days later, respectively. Grasspea, hyacinth and asparagus cells budded intensively. Moreover, the cellulosic material of the cell wall was disorganized and unevenly distributed in lupin, asparagus and hyacinth. In all the tested species arabinogalactan proteins (AGPs) were detected mainly in spherical cells with condensed cytoplasm, but were absent in the budding cells. Notwithstanding the observed differences among species, we concluded that incorrect cell wall structure/composition, together with a deregulated cell cycle might contribute to protoplast recalcitrance in the examined plants. Abnormalities could be a result of the isolation process itself and defective stress-recovering mechanisms. Subsequently, these could arrest regeneration competences and direct cells at apoptotic pathways.
\end{abstract}

Keywords: protoplast culture, cell wall, cellulose, arabinogalactan proteins, recalcitrance

\section{Introduction}

Numerous monocotyledonous and leguminous plant species are regarded as recalcitrant to the protoplast culture (Wang et al., 1991; Rybczyński, 2001; Pindel, 2002). Cells and tissues of such plants cannot acquire the ability to regenerate new tissues and organs even under optimal conditions (Sedira, 2006). Disturbances in their morphological plasticity limit successful in vitro propagation of recalcitrant species. The protoplast culture is a particularly exacting culture system in which isolated protoplasts have to cope not only with developmental reprogramming, but also with a serious infringement of cell integrity. Although enzymatic digestion of cell wall components is essential for protoplast production, it also induces a stress reaction, from which protoplasts have to recover in an artificial environment. As is known from pioneering studies on protoplasts (Pojnar et al., 1967; Nagata and Takebe, 1970), only protoplasts that have reconstructed their cell wall are capable of dividing. Therefore, correct resynthesis of the cell wall is an indispen- sable precondition for subsequent mitoses and establishment of a proliferating cell suspension (Tylicki et al., 2001). Studies on cell wall biosynthesis have usually been conducted on protoplasts which easily divide in culture (e.g. Solanaceae representatives) (Wang et al. 1991). However, little is known about cell wall regeneration in protoplast cultures of recalcitrant plants, such as numerous grain legumes and monocots. Thus, for these species, it is essential to distinguish cellular events that are related to protoplast inability to maintain morphogenetic competences (Wiszniewska and Pindel, 2010). Among the factors that influence protoplast development in culture are the composition and structure of the newly regenerated cell wall, as well as the rate of its reconstruction (Kinnersley et al., 1978). Moreover, some cell wall components may play a role in the induction of the morphogenetic potential in cultured protoplast-derived cells. In this regard, the stimulation of differentiation processes in plants has been attributed to the presence and function of arabinogalactan proteins (AGPs). 
These cell-wall proteoglycans have been proven to alter the course of the in vitro development of plant cells and tissues (Wiśniewska and Majewska-Sawka, 2007; Shibaya and Sugawara, 2009). Therefore, insight into the involvement of these proteins in cell-wall regeneration and cell differentiation is particularly desirable in cultures of recalcitrant species.

We hypothesized that protoplast recalcitrance is correlated with disturbed/improper biosynthesis of a new cell wall. Therefore, the aim of the present study was to examine the process of cell-wall regeneration in protoplast cultures of four recalcitrant plant species: yellow lupin and grasspea (both belonging to grain legumes), and ornamental monocots: hyacinth and asparagus. During the early days of culture the rate of cell wall resynthesis was investigated together with the arrangement of cellulosic microfibrils on the surface of protoplast-derived cells. The localization of AGPs in protoplast-derived cells was also performed to evaluate the level of these proteins in the cell walls of protoplast-derived cells.

\section{Materials and methods}

\section{Plant material}

Two ornamental monocots: Asparagus densiflorus "Sprengeri" (Kunth) Jessop and Hyacinthus orientalis L. "Anna Lisa”, and two grain legumes: Lathyrus sativus L. "Derek" and Lupinus luteus L. "Parys" were used as plant material. For each of the examined species the optimal explant origin and conditions for protoplast isolation and culture had earlier been established in our department (Pindel, 1997; Pindel and Lech, 2002; Wiszniewska and Pindel, 2009; Piwowarczyk and Pindel, 2011).

\section{Protoplast isolation}

Grasspea protoplasts originated from leaves of in vitro seedlings. Surface sterilized seeds were transferred onto a solidified medium composed of MS salts and $2 \%$ sucrose. Cultures were stored for a 16 -h photoperiod (irradiance $80 \mathrm{mmol} / \mathrm{m}^{2} / \mathrm{s}$ ) at $24 \pm 2^{\circ} \mathrm{C}$. Protoplasts were isolated from leaves of 3-week-old seedlings. Leaves, with lower epidermis removed, were incubated overnight in an enzyme mixture containing $1 \%$ Cellulase Onozuka R-10 (Kinki Yakult Co., Ltd, Nishinomiya, Japan), 0.5\% Macerozyme Onozuka R-10 (Kinki Yakult Co., Ltd, Nishinomiya, Japan) and 11\% sorbitol. Yellow lupin protoplasts were isolated from cotyledons of in vitro seed- lings. Seedlings were obtained as described above. Protoplasts were isolated according to Wiszniewska and Pindel (2009): 18-day-old cotyledons were sliced and placed in $10 \mathrm{ml}$ of enzyme solution consisting of $2 \%$ Cellulase Onozuka R-10, 1\% Pectinase (Sigma, Chemical Co., St. Louis, MO, USA) and $14 \%$ sorbitol. The tissue was incubated for $3 \mathrm{~h}$ on a gyratory shaker at $80 \mathrm{rpm}$.

Asparagus protoplasts were isolated from young shoots of glasshouse plants, according to Pindel (1997). In brief, 3-day-old spears were surface sterilized and thinly sliced, followed by overnight incubation in $10 \mathrm{ml}$ of enzyme solution containing $1.2 \%$ Cellulysin (Calbiochem, La Jolla), 0.3\% Macerozyme Onozuka R-10, 1.0\% Rhozyme (Rohm and Haas Co., Philadelphia, USA) and $9 \%$ sorbitol.

Hyacynth protoplasts were obtained from etiolated in vitro shoots. Shoots regenerated from bulb scales were placed on MS medium supplemented with $1.1 \mathrm{mg} / 1$ BAP and $0.11 \mathrm{mg} / 1 \mathrm{NAA}$, and incubated in darkness at $26^{\circ} \mathrm{C}$. Isolation was conducted according to Pindel and Lech (2002). In short, shoots were thinly sliced and incubated overnight in $10 \mathrm{ml}$ of enzyme solution containing 3.0\% Cellulase Onozuka R-10, 1.2\% Macerozyme Onozuka R-10, 0.5\% Pectinase and 8\% sorbitol.

All enzymatic mixtures were prepared in $0.1 \%$ MES [2-(N-morpholino) ethanesulfonic acid] buffer in CPW salts (Frearson et al., 1973). Protoplasts were purified by filtration through a $100-\mathrm{mm}$ nylon-mesh filter and afterwards were rinsed three times with a sorbitol solution in $\mathrm{CPW}$ and twice with the respective culture medium.

\section{Protoplast culture}

Protoplasts were cultivated in liquid media of an optimal basic composition, supplemented with respective growth regulators. Asparagus protoplasts were cultivated in a liquid medium based on MS medium formulation (Murashige and Skoog 1962), enriched with $0.5 \mathrm{mg} / 1$ BAP, $1.0 \mathrm{mg} / 1 \mathrm{NAA}, 1.0 \mathrm{mg} / 1$ 2,4-D, $100 \mathrm{mg} / 1 \mathrm{~L}$-glutamine, $20 \mathrm{mg} / 1$ casein hydrolyzate and $0.1 \mathrm{mg} / \mathrm{l} \mathrm{L}$-serine. The culture density was adjusted to $1 \times 10^{5} / \mathrm{ml}$. Hyacinth protoplasts were cultured in V-47 medium (Binding, 1974), containing $1.0 \mathrm{mg} / \mathrm{l} \mathrm{NAA}, 1.4 \mathrm{mg} / \mathrm{l}$ 2,4-D and $0.5 \mathrm{mg} / \mathrm{l}$ zeatin, at a density of $1 \times 10^{5} / \mathrm{ml}$. Yellow lupin protoplasts were cultured at a density of $2 \times 10^{5} / \mathrm{ml}$ in modified $\mathrm{B}_{5}$ medium (Gamborg et al., 1968), supplemented with $20 \mathrm{mg} / \mathrm{l}$ ascorbic acid, growth regulators: NAA, 
BAP, 2,4-D, 2iP and $\mathrm{GA}_{3}$, each at a concentration of $0.5 \mathrm{mg} / \mathrm{l}$, and $0.1 \%(\mathrm{w} / \mathrm{v})$ activated charcoal. The grasspea protoplast culture was also established in a modified $\mathrm{B}_{5}$ medium, supplemented with $20 \mathrm{mg} / 1$ ascorbic acid and growth regulators: NAA, BAP, 2,4-D, 2iP and $\mathrm{GA}_{3}$, each at a concentration of $0.5 \mathrm{mg} / \mathrm{l}$, and $5 \mathrm{mg} / \mathrm{l}$ chitosan (Sigma). The protoplast density was adjusted to $1 \times 10^{5} / \mathrm{ml}$. Cultures were maintained in the dark at $27^{\circ} \mathrm{C}$.

\section{Cell wall staining procedures}

Cellulosic cell wall. The regenerated cell walls of cultured protoplasts were stained with Fluorescent Brightener 28 (the active component of Calcofluor White ST, Sigma Chemical Co.). Protoplasts were collected on the 1st, 2nd, 5th, 7th and 10th day of cultivation and stained for 5 min with $0.01 \%$ Calcofluor in sorbitol. This fluorescent dye is excited by ultraviolet light at $365 \mathrm{~nm}$ and binds to cellulose which fluoresces in blue. An AxioImager M2 (Zeiss) multifunctional microscope was used to examine the stained specimens. Photographic documentation was created using a PowerShot G10 (Canon) camera and the AxioVision Rel. 4.8. (Zeiss) software program.

Arabinogalactan proteins (AGPs). 0.01\% $\beta$-D-glucosyl Yariv reagent (Biosupplies, Australia Pty. Ltd.) in $0.15 \mathrm{M}$ $\mathrm{NaCl}$ was used to detect arabinogalactan proteins in the regenerated cell walls of $1,2,5,7$ and 10-day-old protoplasts. The collected protoplasts were stained for $30 \mathrm{~min}$ and examined under a Nikon Eclipse E400 microscope. Cell walls containing AGP proteins stained red-brown. A JVC TK1380 video camera and the ImagePro Plus (Media Cybernetics) software program were used to create the photographic documentation.

\section{Results}

\section{Grasspea "Derek"}

Cell wall regeneration by grasspea protoplasts was relatively quick. After 24 hours of cultivation over $50 \%$ of grasspea mesophyll protoplasts reconstructed their cell walls (Fig. 1). A significant increase in the number of protoplast-derived cells was observed between the 2nd and 7th day of culture. After 10 days of culture about $90 \%$ of cultivated protoplasts had cell walls. No divisions were observed during the culture period. On the other hand, budding protoplasts constituted about 18\%of the 10-day-old culture population (Fig. 2A). Microsco-

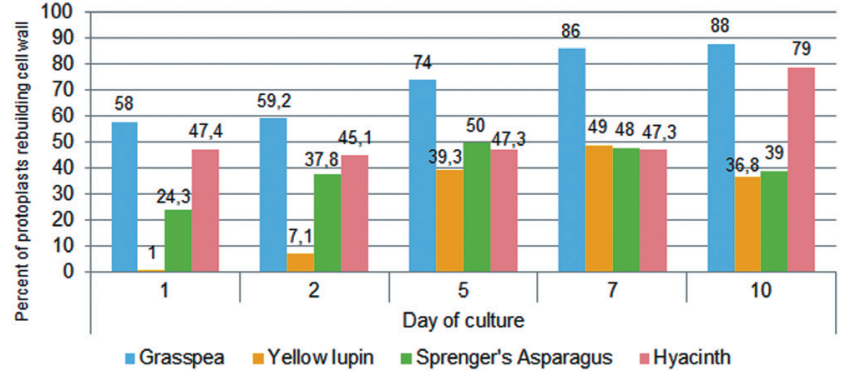

Fig. 1. Percentage of protoplasts with regenerated cellulosic cell walls after $1,2,5,7$ and 10 days of culture

pic observations revealed that cellulose was also synthesized on the cell membrane of embossing protoplast fragments ("buds") (Fig. 2B and Fig. 2C).

Arabinogalactan proteins were detected in $16 \%$ of protoplast-derived cells [AGP(+)] on the 2nd day of culture and in $38 \%$ on the 5 th day. Cell walls were rather thick, so intensive red staining was easily observed (Fig. $3 \mathrm{~A}-$ Fig. 3C). AGP $(+)$ cells remained spherical, with condensed cytosol. AGPs were not detected in viable budding cells. Also, in a 1-week-old culture, no cells with red-stained cell walls were found.

\section{Yellow lupin "Parys"}

Among the examined species, the rate of cell wall reconstruction was the slowest in the culture of yellow-lupin cotyledonary protoplasts. During the first two days of culture we sporadically observed protoplast-derived cells with a newly regenerated cell wall (1-3 in the analyzed field) (Fig. 1). On the 7th day only half of the culture population was represented by cells. Interestingly, there was a clear decrease in the number of regenerated cells on subsequent days of culture. Occasionally, viable and enlarged protoplasts without cell walls were observed after the 10th day of culture (Fig. 2D and Fig. 2E). Additionally, thinner cellulose layers, as well as noticeable "holes" without cellulosic material were often visible in newly regenerated cell walls (Fig. 2F).

The cytochemical detection of arabinogalactan proteins revealed that few cells regenerated during the first 2-4 days contained AGPs in their cell walls. These cells remained spherical or were slightly elliptical, with a very dense cytoplasm and condensed chloroplasts (Fig. 3D). During the subsequent days, the percentage of AGP $(+)$ cells increased up to $40 \%$ on the 7 th day. Cells that did not react with Yariv reagent remained viable for about three weeks, but failed to divide. Nearly $80 \%$ of these $\mathrm{AGP}(-)$ cells presented abnormalities in the cell wall 


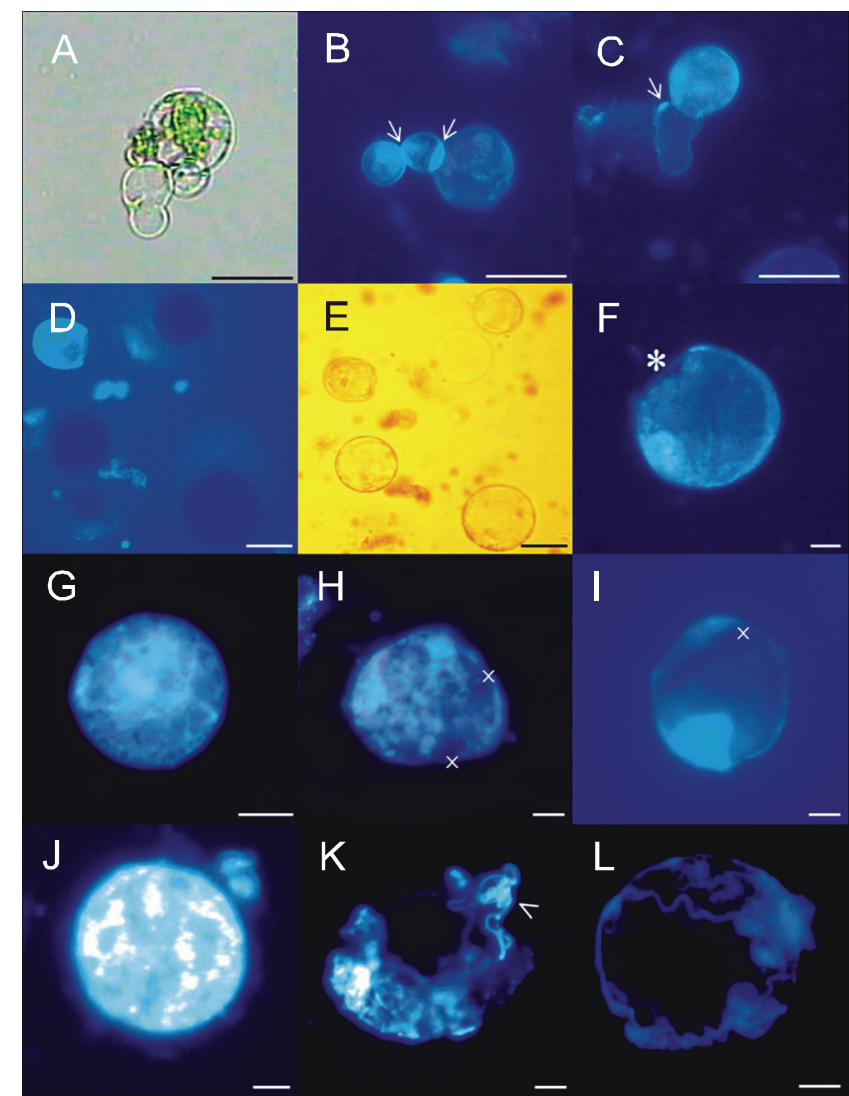

Fig. 2. Regeneration of cellulosic cell walls of cultured protoplasts: A-C) Budding Lathyrus sativus protoplasts; B-C) Fluorescent cell-wall material visible on "buds" (arrows); D-F) Lupinus luteus protoplasts; D-E) Protoplasts without cell walls after 10 days of culture; F) Unequal distribution of cellulose on protoplasts led to the formation of "a hole" in the cell wall layer (asterisk); G-I) Asparagus densiflorus protoplasts; G) Small protoplast evenly covered by cell-wall material; H-I) Unequal distribution of cellulose on the surface of a larger protoplast (crosslet); J-L) Hyacinthus orientalis protoplasts; J) Protoplast with a completely regenerated cell wall; K-L) Irregular thickenings on the surface of protoplast; K) Protoplast losing part of its cell-wall material into the culture medium (arrowhead). Bar: A-E - $50 \mu \mathrm{m}, \mathrm{F}-\mathrm{L}-10 \mu \mathrm{m}$

structure, such as "holes" and irregular, curly surfaces (Fig. 3E - Fig. 3G).

\section{Asparagus "Sprengeri"}

Asparagus protoplasts isolated from ex vivo young shoots also rebuilt their cell wall slowly. The first observation (after 24 hours) demonstrated that about one quarter of the cultivated protoplasts regenerated cell walls (Fig. 1). The highest cell wall resynthesis ratio, i.e. $50 \%$, was reached on the 5 th day, and the number gradually decreased during subsequent days. Small protoplasts $(<30 \mu \mathrm{m}$ in diameter) regenerated cell walls fas-

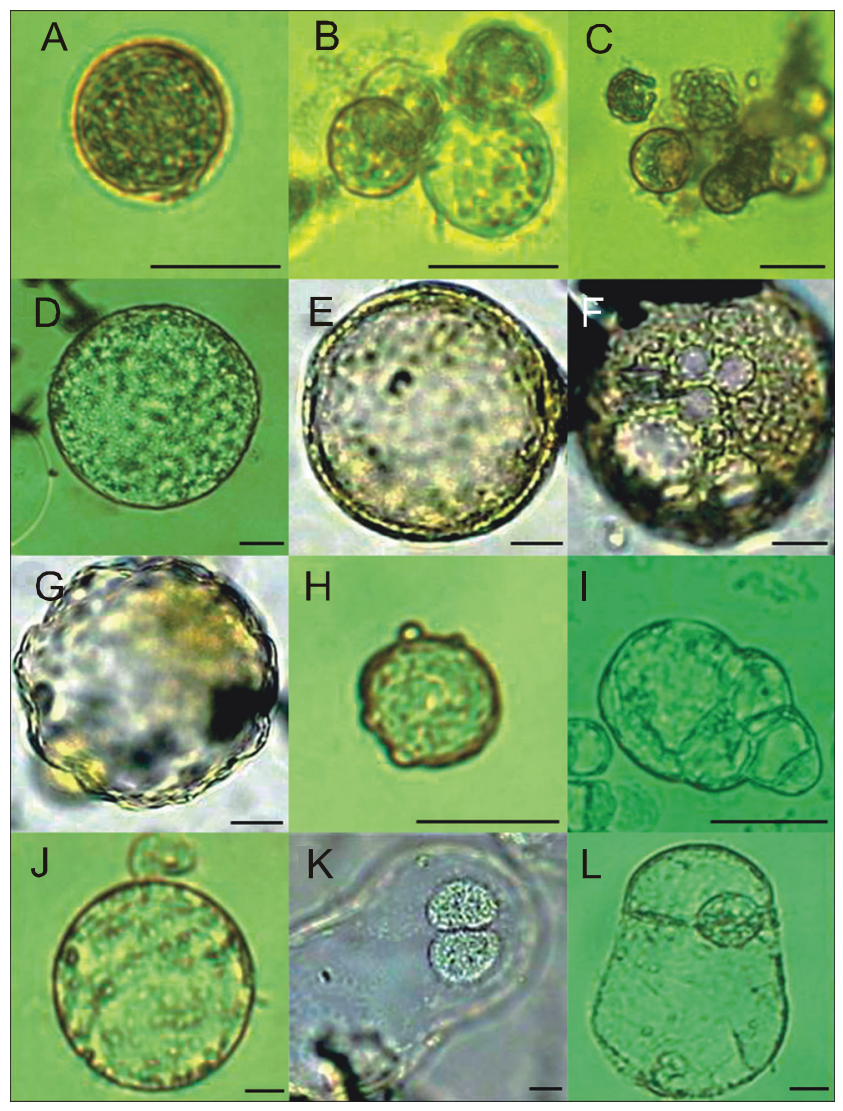

Fig. 3. Cytochemical detection of arabinogalactan proteins (AGPs) in regenerated cell walls of cultured protoplasts: A-C) Spherical AGP(+) protoplast-derived cells of Lathyrus sativus D) Spherical AGP $(+)$ protoplast-derived cell of Lupinus luteus; E-G) Abnormalities in AGP(-) cell walls of Lupinus luteus cells; H) AGP(+) protoplast-derived cell of Asparagus densiflorus. I) Budding AGP(-) cell of Asparagus densiflorus; J) Spherical AGP(+) protoplast-derived cell of Hyacinthus orientalis; K) Karyokinesis without cytokinesis in budding AGP(-) cell of Hyacinthus orientalis; L) Uninuclear cell of Hyacinthus orientalis with partial phragmoplast. Bar: A-C, H, J - $50 \mu \mathrm{m}$,

$$
\text { D-G, J-L - } 10 \mu \mathrm{m}
$$

ter and in a more regular manner than larger ones (Fig. 2G). The latter, however, exhibited an irregular deposition of cellulose and thin wall areas (Fig. $2 \mathrm{H}$ and Fig. 2I).

In asparagus culture no $\mathrm{AGP}(+)$ cells were detected until the 5th day of culture, when the number of these cells accounted for $4 \%$. On the surface of AGP(+) cells tiny vesicles were apparent (Fig. $3 \mathrm{H}$ ). Interestingly, AGPs were not detected in protoplast-derived cells in the subsequent days of culture evaluation. Nevertheless, budding and incipient mitoses occurred (Fig. 3I).

\section{Hyacinth "Anna Lisa"}

About $45 \%$ of hyacinth protoplasts regenerated cell walls after one day of cultivation, and in the following 
days the frequency of protoplast-derived cells did not change (Fig. 1). It increased suddenly after 10 days of culture. However, a complete cell wall was seldom observed (3\%) (Fig. 2J). Instead, incomplete wall regeneration was predominant, resulting in budding and the formation of wrinkled cellulosic thickenings (Fig. $2 \mathrm{~K}$ and Fig. 2L).

In $43 \%$ of cell walls regenerated during the early stages of culture (2nd to 5th day) an AGP-positive reaction was detected (Fig. 3J). Among the examined plant species, staining with Yariv reagent was the most intensive in hyacinth protoplasts. On the other hand, cultured AGP(-) cells budded and formed elongated chains. Interestingly, karyokinesis quite often occurred with no following cytokinesis (16\%) (Fig. 3K). Multinuclear cells were both spherical and non-spherical. Uninuclear cells with partial phragmoplast were seldom visible (1-2 in the analyzed field) (Fig. 3L).

\section{Discussion}

Regeneration of cell wall is the first visible activity taken up by isolated protoplasts and the success of this process determines the subsequent behavior of protoplasts in culture. For this reason cell wall resynthesis may be regarded as a first step in reprogramming and dedifferentiation in protoplast culture. Numerous papers dealing with cell wall regeneration were published during the heyday of studies into protoplast cultures in the 1970 s and 80 s when mainly the easily regenerating species were used as experimental objects (Pojnar et al., 1967; Nagata and Takebe, 1970; Willison and Grout, 1978; Burgess et al., 1978). On the other hand, reports on cellular rearrangements of recalcitrant protoplasts are rare, perhaps because, unfortunately, their scientific contribution is often underestimated.

The process of cell wall reconstruction in yellow lupin, grasspea and hyacinth protoplast cultures has not been described to date. However, some new data are currently being interpreted in our laboratory. The experiments described here revealed that in yellow lupin resynthesis began late and the increase in protoplastderived cells was the slowest. To explain a similar phenomenon, Burgess et al. (1978) postulated that protoplasts might not be competent to synthesize microfibrils immediately after their removal from wall-degrading enzymes, and the lag period might be required for the protoplasts to assemble their cellulose-synthesizing machinery. It is also probable that very low concentrations of cellulose were not detected during the early days of culture (van Amstel and Kengen, 1996). However, in lupin culture, cell wall renewal was decidedly a defective process, and affected not only protoplast morphology, but also their viability. In a culture older than 10 days protoplast-derived cells gradually collapsed, while protoplasts without cellulosic deposits remained viable. Therefore, incorrect cell wall structure/ composition might be among the reasons for protoplast recalcitrance in this species.

In contrast, grasspea and hyacinth protoplasts regenerated cell walls within one day of culture. As suggested by Tylicki et al. (2001), a high percentage of regenerating cells indicates an appropriate culture environment for cell wall renewal. Surprisingly, the number of protoplast-derived cells obtained was slightly higher than in the culture of the highly-responsive Solanum lycopersicoides (Tylicki et al., 2001). However, in grasspea and hyacinth the cellulose layer was incomplete and cells intensively budded, instead of dividing. Moreover, cell wall materials were often not tightly attached to the membrane. Similarly, loose and disorganized cell wall fibrils were observed in recalcitrant mesophyll protoplasts of maize (Wang et al., 1991). Considering the budding phenomenon, Tao and Verbelen (1996) revealed that in a tobacco protoplast culture, synthetic auxin NAA acted as a powerful morphogenetic signal and even at low concentrations $(0.065 \mathrm{mg} / \mathrm{l})$ cell budding was strongly inhibited. This contrasts with our results, where protoplasts budded even if cultured in media containing high NAA dosages $(0.5$ and $1.0 \mathrm{mg} / \mathrm{l}$ for grasspea and hyacinth, respectively). Additionally, we observed clear symptoms of a deregulated cell cycle in hyacinth protoplasts (polynuclear cells, karyokineses without cytokineses). It can be hypothesized that the recalcitrance resulted from the stress encountered during isolation and cultivation.

Available reports on plant regeneration from various species of asparagus rarely provide information on cell wall regeneration. In a callus-derived protoplast culture of Asparagus densiflorus “Sprengeri” resynthesis began within $24 \mathrm{~h}$ of culture, and after 7 days up to $10 \%$ of the surviving cells were oval and budded (Benmoussa et al., 1997). Our results support the observation that protoplasts of asparagus quickly undertake cell wall re- 
newal. However, we observed only incipient mitoses along with budding. Protoplast-derived cells with incomplete cell walls were enlarged. It can be suggested that a weak and disorganized cell wall led to a turgor-driven cell expansion (Wang et al., 1991).

We observed that the presence of AGPs in cell walls was an indicator of cell death. Perhaps, as a result of the isolation stress, cell walls were defectively regenerated and proteoglycans were improperly bound to the plasma membrane. The involvement of AGPs in the deposition and assembling of cell wall subunits has been described in several plant species (Roy et al., 1998; Shibaya and Sugawara, 2009). There is also evidence that AGPs are markers of cells entering apoptotic pathways (Gao and Showalter, 1999; Shibaya and Sugawara, 2007). In this respect, this was a probable developmental fate of the protoplasts examined in this study.

\section{Conclusions}

In our study the recalcitrance of the examined plant species to the protoplast culture was confirmed. It can be suggested that unbalanced cell wall renewal, together with a deregulated cell cycle, contributes to the limited potential of plant regeneration in these species. Further studies are necessary to better understand the origin of the observed abnormalities. Future studies ought to include analyses of the changes in cytoskeleton conformation, identification of polysaccharides and non-polysaccharide components in newly rebuilt cell walls, as well as recognition of the cellular machinery responsible for the morphogenetic plasticity in cultured protoplasts. Significant advances in knowledge can yet be derived from studies on easily-regenerating protoplast cultures, but the findings will nevertheless have to be verified in recalcitrant systems. Further studies on recalcitrant plant protoplasts may contribute to the overcoming of existing limitations.

\section{References}

Benmoussa M., Mukhopadhyay S., Desjardins Y. (1997) Factors influencing regeneration from protoplasts of Asparagus densiflorus cv. Sprengeri. Plant Cell Rep. 17: 123-128.

Binding H. (1974) Regeneration von haploiden und diploiden Pflanzen aus Protoplasten von Petunia hybrida. Zeitschr. Pflanzenphysiol. 74: 327-356.

Burgess J., Linstead P.J., Bonsall V.E. (1978) Observations on the time course of wall development at the surface of isolated protoplasts. Planta 139: 85-91.
Frearson E.M., Power J.B., Cocking E.C. (1973) The isolation, culture and regeneration of Petunia leaf protoplasts. Dev. Biol. 33: 130-137.

Gamborg O.L., Miller R.A., Ojima K. (1968) Nutrient requirements of suspension culture of soybean root cells. Exp. Cell Res. 50: 151-158.

Gao M., Showalter A.M. (1999) Yariv reagent treatment induces programmed cell death in Arabidopsis cell cultures and implicates arabinogalactan protein involvement. Plant J. 19: 321-332.

Kinnersley A.M., Racusen R.H., Galston A.W. (1978) A comparison of regenerated cell walls in tobacco and cereal protoplasts. Planta 139: 155-158.

Murashige T., Skoog F. (1962) A revised medium for rapid growth and bioassays with tobacco tissue cultures. Physiol. Plant. 15: 473-497.

Nagata T., Takebe I. (1970) Cell wall regeneration and cell division in isolated tobacco mesophyll protoplasts. Planta 92: 301-308.

Pindel A. (1997) Preliminary studies on obtainment of ornamental asparagus (Asparagus densiflorus Jesson 'Sprengeri') protoplasts (in Polish). Zesz. Nauk. AR w Krakowie. Ogrodnictwo 23: 73-80.

Pindel A., Lech M. (2002) The effect of the explant type on protoplast isolation efficiency of some monocot ornamental plant species (in Polish). Zesz. Prob. Post. Nauk. Roln. 488: 571-576.

Piwowarczyk B., Pindel A. (2011) Isolation and culture of grasspea (Lathyrus sativus L.) protoplasts - studies on viability and cell wall reconstruction. Abstracts of the IV Congress of Polish Biotechnology and "IV EUROBIOTECH 2011" Central European Congress of Life Sciences Kraków, Poland 12-15th October, 101.

Pojnar E., Willison J.H., Cocking E.C. (1967) Cell wall regeneration by isolated tomato fruit protoplasts. Protoplasma 64: 460-480.

Roy S., Jauh G.Y., Hepler P.K., Lord E.M. (1998) Efects of Yariv phenylglycoside on cell wall assembly in the lily pollen tube. Planta 204: 450-458.

Rybczyński J.J. (2001) Lupin biotechnology (in Polish). Zesz. Nauk. AR we Wrocławiu, Rolnictwo 82 (427): 93-114.

Sedira M. (2006) Studies of adventitious root formation in woody species. Doctoral Thesis, Swedish University of Agricultural Sciences, Alnarp.

Shibaya T., Sugawara Y. (2007) Involvement of arabinogalactan proteins in the regeneration process of cultured protoplasts of Marchantia polymorpha. Physiol. Plant. 130: 271279.

Shibaya T., Sugawara Y. (2009) Induction of multinucleation by b-glucosyl Yariv reagent in regenerated cells from Marchantia polymorpha protoplasts and involvement of arabinogalactan proteins in cell plate formation. Planta 230: 581-588

Tao W., Verbelen J.-P. (1996) Switching on and off cell division and cell expansion in cultured mesophyll protoplasts of tobacco. Plant Sci. 116: 107-115. 
Tylicki A., Burza W., Malepszy S., Kuraś M. (2001) Regeneration of the cell wall by isolated protoplasts of Solanum lycopersicoides Dun. is a selective process. Biol. Bull. Poznań 38: 97-101.

Van Amstel T.N.M., Kengen H.M.P. (1996) Callose deposition in the primary wall of suspension cells and regenerating protoplasts, and its relationship to patterned cellulose synthesis. Can. J. Bot. 74: 1040-1049.

Wang H., Slater G.P., Fowke L.C., Saleem M., Cutler A. (1991) Comparison of cell wall regeneration on maize protoplasts isolated from leaf tissue and suspension cultured cells. In Vitro Cell Dev. Biol. 27P: 70-76.

Willison J.H.M., Grout B.W.W. (1978) Further observations on cell-wall formation around isolated protoplasts of tobacco and tomato. Planta 140: 53-58.
Wiśniewska E., Majewska-Sawka A. (2007) Arabinogalactanproteins stimulate the organogenesis of guard cell protoplasts-derived callus in sugar beet. Plant Cell Rep. 26: 1457-1467.

Wiszniewska A., Pindel A. (2009) Improvement in Lupinus luteus (Fabaceae) protoplast culture - stimulatory effect of agarose embedding and chemical nursing on protoplast divisions. Austral. J. Bot. 57: 502-511.

Wiszniewska A., Pindel A. (2010) Cellular aspects of regeneration in protoplast culture of yellow lupin (Lupinus luteus L.) (in Polish). Biotechnologia 2(89): 18-22. 